\title{
Misfolded protein aggregation and altered cellular pathways in neurodegenerative diseases
}

\author{
Huifang $\mathrm{LI}^{1,2}$, Zhenghong $\mathrm{YU}^{3,{ }^{*}}$, Wei ZHANG ${ }^{1,2,{ }^{*}}$ \\ ${ }^{1}$ College of Animal Science and Technology, Nanjing Agricultural University, Nanjing 210095, China. \\ ${ }^{2}$ National Experimental Teaching Demonstration Center of Animal Science, Nanjing Agricultural University, Nanjing 210095, China. \\ ${ }^{3}$ Department of Rheumatology and Immunology, Jinling Hospital, Medical School of Nanjing University, Nanjing 210002, China. \\ *Correspondence: weizhang@njau.edu.cn, m fish@189.cn \\ https://doi.org/10.37175/stemedicine.v1i4.63
}

\begin{abstract}
Neurodegenerative diseases are estimated by the World Health Organization to be the second leading cause of human death by 2050 . They actually are a group of chronic neurological disorders leading to motor, cognitive and sensory impairments in both human and nonhuman species. Despite different in clinical manifestation, prevalence, risk factors, cell types injured and genes hijacked, neurodegenerative disorders are usually associated with the misfolding and aggregation of a distinct protein that accumulates in diverse cellular locations including the nucleus, cytoplasm, plasma membrane and extracellular space. Here we intend to give an overview of the characteristics and features of several pathogenic protein aggregates in disease brains, and introduce some general signaling pathways involved in protein homeostasis with an emphasis on their puzzling roles under the degenerative conditions.
\end{abstract}

Keywords: Neurodegenerative diseases · Misfolded protein aggregates · Unfolded protein response $\cdot$ Protein clearance pathways · Insulin/IGF/TOR

\section{Introduction}

Neurodegenerative diseases (NDs) are chronic neurological disorders including Alzheimer's disease (AD), Parkinson's disease (PD), Huntington's disease (HD), Creutzfeldt-Jakob disease (CJD), Friedreich's ataxia, spinal muscular atrophy (SMA) and amyotrophic lateral sclerosis (ALS) in humans, as well as scrapie in sheep and goats, bovine spongiform encephalopathy (BSE) in cattle and several others in nonhuman species (1-7). Although these diseases are initiated predominantly by aggregations of different misfolded proteins, they all result in gradual and progressive loss of nerve cells in the brain, eventually leading to irreversible disability in learning and memory due to impaired motor, sensory and cognitive systems. Pathologic development of neurodegenerative disorders usually is slow but fatal, requiring the accumulation of pathogenic molecules to exceed some

Received: July 17, 2020; Accepted: Sep 9, 2020.

(9) The Author(s). 2020 This is an Open Access article distributed under the terms of the Creative Commons License (http://creativecommons.org/licenses/by/4.0/) which permits unrestricted use, distribution, and reproduction in any medium or format, provided the original work is properly cited. critical threshold before neurological dysfunction occurs. Many NDs therefore are not evolutionarily selected and associated with the aging process, which provides time to allow the neurogenic symptoms to manifest (8). It was estimated by the World Health Organization that NDs should replace cancer, becoming the second leading cause of human death by 2050, when senior people aged 65 and above reach $17 \%$ of the population and over 152 million people are expected to have these dreaded maladies in their later life (9). The numbers underline the urgent need to develop informative molecular diagnostics and effective medical treatment for the public health problem.

While work in the field of neurodegeneration has been sparked by the prevalence of the world-wide epidemic along with increased life expectancy, yet we are only beginning to understand the underlying genetic and cellular mechanisms, and so far limited steps have been made along the path to promising therapeutics for these age-dependent illnesses. In light of this, the goal of this review is to provide an overview of protein misfolding and aggregation in degenerative brain disorders, and focus on debated knowledge regarding the cellular pathways altered in relevance to protein homeostasis under the 
pathological condition. We hope this review will be helpful to inspire new ideas and new discoveries on NDs.

\section{Misfolded pathogenic protein aggregates in NDs}

Although distinct in clinical manifestation, prevalence, regions of brain targeted and cell types injured, neurodegenerative disorders, when considered at the molecular level, share many common features, among which the progressive accumulation of misfolded pathogenic protein aggregates is believed to be the key event (Table 1). The protein aggregates mentioned here can be small and soluble oligomers, large and amorphous assemblies, or highly ordered fibrillary amyloids. A growing body of evidence indicates that these protein agents, such as amyloid $\beta$-protein, tau and $\alpha$-synuclein, when in native states do not exhibit obvious similarities, and in origin can either come from endogenous gene products, or be seeded by an external infectious process, referred to as prion infection.

\subsection{Amyloid $\beta$-protein $(A \beta)$}

Aggregation of misfolded amyloid $\beta$-protein $(A \beta)$, a secreted peptide derived from an internal domain within the amyloid $\beta$-protein precursor $(\beta \mathrm{APP})$, is an invariant hallmark of all forms of $\operatorname{AD}(38,39)$. It is well known that the $\beta$ APP protein is normally synthesized, secreted and then efficiently degraded when the internal domain for $\mathrm{A} \beta$ is cleaved by $\alpha$-secretase, a protease, to prevent $\mathrm{A} \beta$ formation $(40,41)$. However, $\beta A P P$ in normal brain can also undergo cleavage in the endoplasmic reticulum (ER)Golgi secretory pathway by $\beta$ - and $\gamma$-secretase instead of $\alpha$-secretase to release the amyloidogenic fragment, characterized as a 38- to 48-residue peptide (42-45). Among these toxic peptides, $A \beta 42$ is the principal component of amyloid deposits in AD patients as it forms insoluble aggregates much faster than others $(46,47)$.

It is recognized that the majority of $\mathrm{AD}$ cases are sporadic, and only $10 \%$ to $20 \%$ occur in families (48). Nevertheless, in vitro and in vivo studies have showed that the underlying genetic factors, whether sporadic or inherited, are aiming to accelerate the accumulation of $A \beta$ neurotoxicity at multiple levels. The first familial mutation discovered was in the $\beta A P P$ gene, near the putative site for $\gamma$-secretase cleavage, modifying $\gamma$-secretase activity and thereby enhancing only the production of A $\beta 42$ (49-51). After that, more inherited $\beta$ APP variants to facilitate $A \beta$ procession were uncovered (52-54). Subsequent genetic analysis by a large number of AD families also identified mutations in presenilin 1 and 2 genes encoding the catalytic subunits of $\gamma$-secretase to increase $A \beta 42$ level (55-57). In contrast, apolipoprotein E, a cholesterol transporter binding to $A \beta$, is the only well-established genetic factor associated with sporadic $\mathrm{AD}$ through its function to influence the clearance of $A \beta$ in extracellular space (58-60).

\subsection{Tau and tauopathies}

Tauopathies are a diverse group of neurodegenerations characterized by neurofibrillary tangles (NFTs) composed of insoluble and hyper-phosphorylated tau proteins in neurons and glia (61). The protein tau, however, naturally is highly soluble and functions as a microtubule (MT)binding protein to stabilize and promote the assembly of MTs (62). The binding between tau and MT is negatively regulated by the phosphorylation of tau, which is a feature of its pathogenic form (63). In adult human brains, tau is encoded by the MAPT gene to generate six isoforms, containing either three or four MT-binding repeats via alternative mRNA splicing (64). It has been proved in vitro that the MT-binding repeats are both necessary and sufficient for tau to acquire highly ordered $\beta$-sheet structures when it assembles into insoluble NFTs (65). Hence it has been shown that all six isoforms are present and misfolded in disease brains to form a heterogeneous mixture of tau isoforms adopting different conformations, which is probably responsible for the clinical and pathological diversity of tauopathies (66).

As a MT-binding protein, tau is normally considered to function inside a cell, but tau aggregates, likely released from dying or dead neurons, are also detected in the extracellular space where it can be taken up through endocytosis by neighboring cells (34). Once internalized, the small amount of aggregated tau then serves as a seed and transmits a misfolded state specifically to the native tau in healthy cells in a manner similar to prion, which will be discussed later (67). In this way, the disease properties spread from cell to cell along the defined neuroanatomical pathways, causing cellular dysfunctions due to both the physical occupancy of the large tau deposition and the loss of the MT-binding function of tau. Especially the latter, not only disrupts the stabilization of MT cytoskeleton, which is important for the generation and maintenance of neurites, but also suppresses the kinesin-dependent transport of mitochondria, peroxisomes and Golgi-derived vesicles in neurons (68). Shortage of mitochondria and peroxisomes subsequently causes loss of energy production and accumulation of reactive oxygen species, leading to degeneration. In particular, suppression of Golgi-mediated secretion would retain vesicles carrying $\beta A P P$ in the cell body, allowing an enhanced production of toxic $A \beta$ peptides $(69,70)$.

\section{$2.3 \alpha$-synuclein $(\alpha-$ syn)}

$\alpha$-synuclein ( $\alpha$-syn) is a phospholipid-binding protein with a chaperone activity to facilitate presynaptic SNAREcomplex assembly and thereby regulate neurotransmitter release in the presynaptic terminals (71). In the presence of negatively charged lipids, normal $\alpha$-syn folds into amphipathic $\alpha$-helices through its $\mathrm{N}$-terminal repeat region. Missense mutations located in the $\mathrm{N}$-terminal repeats often lead to the conversion of $\alpha$-helices into $\beta$-sheet-rich structures, which ultimately coalesce into characteristic assemblies called Lewy bodies and Lewy neurites in maladies such as PD and Lewy body disease, as well as into glial cytoplasmic inclusions in multiple system atrophy $(20,72-74)$.

As in the case of tau protein, the neuropathological process of $\alpha$-syn lesions is also thought to progress via a 
Table 1. Misfolding and aggregation of pathogenic proteins identified from NDs.

\begin{tabular}{|c|c|c|c|c|}
\hline Misfolded Protein & Gene & Subcellular locations & Diseases & References \\
\hline Amyloid $\beta$ & $\beta A P P$ & ER-Golgi, autophagosome, mitochondria, ES & $\mathrm{AD}, \mathrm{PD}$ & $(10-13)$ \\
\hline Androgen receptor & $A R$ & cytosol & SBMA & (14) \\
\hline Atrophin 1 & ATN1 & nucleus, cytosol & DRPLA & (15) \\
\hline Ataxin 1 & $S C A 1$ & nucleus & SCA & (16) \\
\hline$\alpha$-Synuclein & $S N C A$ & nucleus, cytosol, ER, mitochondria, PM, ES & DLB, PD & $(2,17-20)$ \\
\hline Fused in sarcoma & FUS & nucleus, cytosol & ALS, FTD & (21) \\
\hline Huntingtin & $H T T$ & nucleus, cytosol & HD & (22) \\
\hline Prion protein & $P R N P$ & nucleus, cytosol & CJD, Kuru, BSE, CWD, Scrapie & $(7,23-26)$ \\
\hline Rhodopsin & RHO & ER, PM & ADRP & (27) \\
\hline Superoxide dismutase 1 & SOD1 & nucleus, cytosol, ER, mitochondria & ALS & $(28)$ \\
\hline Tau & $M A P T$ & nucleus, cytosol, ER, Golgi, lysosome, PM, ES & AD, FTD, Pick's disease & $(29-35)$ \\
\hline TAR DNA-Binding Protein 43 & TARDBP & nucleus, cytosol & ALS, FTD & $(21,36,37)$ \\
\hline
\end{tabular}

AD: Alzheimer disease; ADRP: Autosomal dominant retinitis pigmentosa; ALS: Amyotrophic lateral sclerosis; $\beta$ APP: amyloid $\beta$-protein precursor; BSE: Bovine spongiform encephalopathy; CJD: Creutzfeldt-Jakob disease; CWD: Chronic wasting disease; DLB: Dementia with Lewy bodies; DRPLA: Dentatorubral-pallidoluysian atrophy; ER: endoplasmic reticulum; ES: extracellular space; FTD: Frontotemporal dementia; HD: Huntington's disease; MAPT: microtubule-associated protein tau; PD: Parkinson's disease; PM: plasma membrane; SBMA: Spinal and bulbar muscular atrophy; SCA: Spinocerebellar ataxia; SNCA: Synuclein Alpha.

seed-induced conversion among cells along anatomically connected structures in the brain, albeit how pathological $\alpha$-syn exits cells remains elusive (75). Furthermore, compelling evidence has suggested that abnormal $\alpha$-syn is frequently co-depositing with other pathogenic proteins like $\mathrm{A} \beta$ and tau, as hybrid polymers initiated by crossseeding between different types of protein aggregates have been extensively reported in various NDs $(76,77)$. As a result, the pathological overlap between disease agents in the same patient raises the question of which one is the predominant cause and complicates the diagnosis and treatment for NDs.

\subsection{Prion diseases}

Prion diseases, such as CJD and Kuru in humans, as well as scrapie and BSE in animals, can arise sporadically, be inherited, or be acquired by infection under natural conditions. The term "prion", denoting a small proteinaceous infectious particle, was proposed by Stanley Prusiner in 1982 first to describe the scrapie agent that causes a degenerative disorder of the central nervous system in sheep and goats (7). The definition now has been broadened to emphasize the requirement of an unconventional and virus-like protein for infection, which is able to undergo self-replication, similar to nucleic acid molecules, but resistant to procedures with specificity for attacking nucleic acids (78). Hence, it is now widely accepted that the pathogen of prion diseases might not contain any DNA or RNA, unless more sensitive probes are developed.
Although prions are thought to exist in multiple strains composed of different polymeric forms of misfolded proteins to cause phenotypic heterogeneity in various brain disorders, they all arise when normal cellular proteins (PrP-Cellular, or $\mathrm{PrP}^{\mathrm{C}}$ ) misfold and transform into pathogenic prion molecules (conventionally referred to as $\mathrm{PrP}-\mathrm{Scrapie}$, or $\mathrm{PrP}^{\mathrm{Sc}}$ ), which are characterized by a high content of $\beta$-sheets. Once established in neurons, the disease agent $\operatorname{PrP}^{\mathrm{Sc}}$ then indefinitely convert more $\operatorname{PrP}^{\mathrm{C}}$ into the prion form. Mutations in the gene encoding PrP have been identified prone to develop infectivity spontaneously $(79,80)$. This perhaps hints a genetic origin of prion diseases, but how pathological transformation occurs when $\operatorname{PrP}^{\mathrm{C}}$ binds to $\operatorname{PrP}^{\mathrm{Sc}}$ is largely unknown. It is predicated that the efficiency of prion conversion could depend on the homology of the primary and secondary structures between $\operatorname{PrP}^{\mathrm{C}}$ and $\operatorname{PrP}^{\mathrm{Sc}}$, and the architecture of the $\operatorname{PrP}^{\mathrm{C}}-\mathrm{PrP}^{\mathrm{Sc}}$ complex (81). According to studies on different prion strains, it is plausible to suspect that environmental factors may also contribute to the conversion of $\operatorname{PrP}^{\mathrm{C}}$ to $\mathrm{PrP}^{\mathrm{Sc}}$ as non-host factors, such as surface binding and weathering, which are able to alter strain emergence in vitro in a population of prions $(82,83)$.

Toxic prions have an enhanced tendency to aggregate and form oligomers or amyloid-like fibrils, disrupting normal cellular functions and eventually spreading within the nervous system mainly through the neural connectome (84). Besides cell-to-cell transmission, person-to-person and even cross-species disseminations are suggested by cumulative evidence as cases were reported that people 


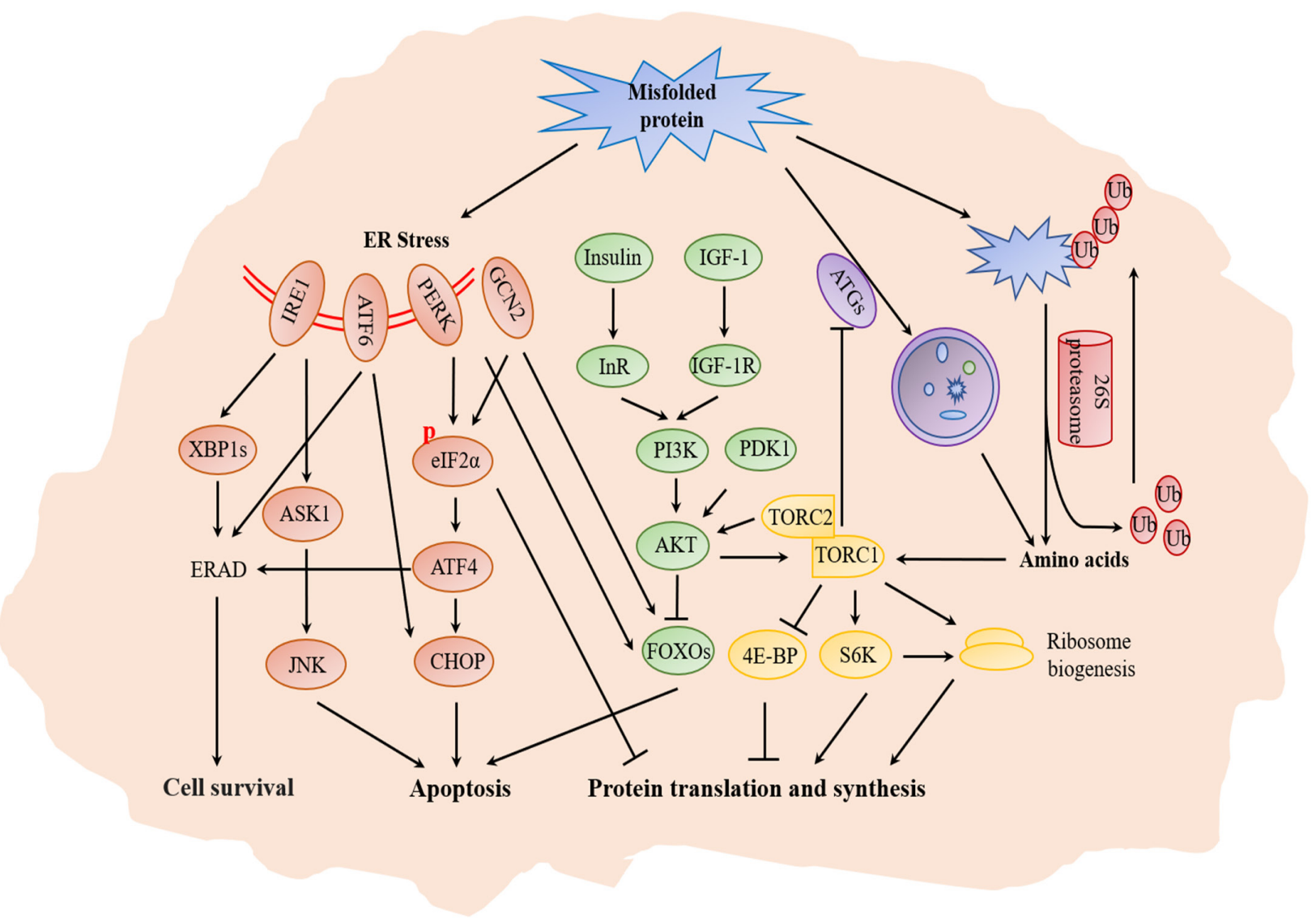

Figure 1. Schematic representation of cellular pathways involved in NDs. Arrows indicate activation, whereas bar-ended lines indicate inhibitory interactions.

with CJD, resulting from consumption of beef prepared from mad cows, transmitted CJD prions to recipients of blood transfusions $(23,85)$. However, the molecular basis of the intra-species and the inter-species transmissibility of prions remains poorly understood.

\subsection{Prion v.s. non-prion}

Even though lots of common biological features are shared, we insist to classify prion and non-prion (A $\beta$, tau, $\alpha$-syn and others) into two groups in this review based on the transmissibility of associated diseases. After all, there is no clinical evidence for the personto-person transmission of non-prion NDs under normal circumstances. Nevertheless, studies with $\mathrm{A} \beta$, tau and $\alpha$-syn have clearly shown that experimental inoculation with brain homogenates from patients or mouse models of these illnesses could lead to disease pathology in recipient animals in laboratory (86-88). As such, it is highly possible that the definition of prion will be further widened when bioassays are well developed so that the transmissibility of non-prion proteins could be fully appreciated. Yet we sincerely hope the infectious property of non-prion diseases is not true as it should challenge the therapeutic strategies and require implementing more precautions in taking care of ND patients. Also, it is serious that to date there are no effective therapies available for prion diseases. Approaches have been explored including small compounds, antibiotics, vaccination, antibodies, peptide aptamer and nucleic acid-based agents, but none have prospects for clinical advancement, owing to either inefficacy against prion after onset of symptoms or inadequate brain distribution. It hereby should be pointed out that a breakthrough from clinical trials can only be achieved with the development of a screening test for the early diagnosis of prion diseases (89).

\section{Alteration of signaling pathways in cells of NDs}

A key question always concerns how the accumulation of distinct disease proteins contributes to the degenerative process. The mechanisms underlying different neurological disorders probably are not exactly the same, but dysregulation of protein homeostasis linked with abnormal aggregates is an almost universal hallmark of ND pathogenesis. In patients, activities of pathways involved in protein synthesis, protein folding, protein degradation and energy supply for proteostasis are altered in cells of the nervous system (Figure 1). However, it is still not completely clear whether these changes play a protective or a toxic role in cell survival.

\subsection{ER stress and unfolded protein response}

The ER plays a central role in protein quality control to 
maintain cellular proteostasis. Membrane and secreted proteins are synthesized, folded and processed in the ER before displayed on the cell surface, or released extracellularly. Misfolded proteins are eliminated via the ER-associated degradation (ERAD) pathways, either the ubiquitin-proteasome system (UPS) or autophagy (also termed as ERAD-I and ERAD-II respectively in some publications), to ensure that only properly folded proteins exit the ER (90). When substrates exhaust the regulatory capacity of ERAD, misfolded proteins accumulate and lead to a stress response called the unfolded protein response (UPR) (91). The UPR is mediated through three principal branches including endoribonuclease IRE1, transcription factor ATF6, and eIF2 $\alpha$ kinases PERK and GCN2. The three signal transducers then regulate the expression of tremendous genes to adapt to the stress or to induce cell apoptosis when the stress cannot be mitigated (92).

In most organisms, ER stress-associated UPR is exacerbated during the aging process $(93,94)$. The capacity of the ER to prevent aberrant protein dramatically decreases in healthy aging, while the burden of unfolded proteins increases instead. In this scenario, the UPR is known to activate its adaptive programs to alleviate the accumulation of misfolded proteins via halting protein translation, stimulating destruction of abnormal proteins by ERAD, and increasing the production of ER chaperons relevant to protein folding. Upon activation, IRE1 is usually acting as an RNase and mediating the removal of an intron from the $X B P 1$ mRNA to allow the expression of a functional XBP1 transcription factor (95). The activity of XBP1 is linked to various pro-survival events including transcription of genes involved in protein folding and ERAD (96). ER stress also directly modulates gene expression to promote cytoprotection through the transcription factor ATF6 after it is translocated from the ER to Golgi, where ATF6 is activated by a proteolytic cleavage (97). In addition, the protein translation initiation factor eIF $2 \alpha$ is phosphorylated upon stress to globally attenuate the cap-dependent mRNA translation and prevent overload of newly synthesized proteins into the already stressed ER lumen (98). In contrast, under eIF2 $\alpha$ phosphorylation, translation of a subset of mRNAs, such as transcription factor ATF4 and genes targeted by XBP1 and ATF6, is enhanced to restore homeostasis via upstream open reading frame (99). Phosphorylation of eIF2 $\alpha$ in response to ER stress was initially found to be controlled by auto-phosphorylation of the ER-resident PERK kinase, and it is recognized now to be partially contributed by GCN2 as well $(100,101)$. Although it remains unclear how the cytoplasmic GCN2 kinase senses ER stress, the redundant regulation of the two eIF $2 \alpha$ kinases was suggested to occur in a tissue dependent manner (102).

ER stress-triggered UPR has been implicated broadly in neurodegeneration. Previous work in a Drosophila model of PD showed that accumulation of wild type or missense mutant $\alpha$-syn led to the hyper-activation of IRE1, and ectopic overexpression of IRE1 was sufficient to induce neuron death, progressive locomotor impairment and shorter lifespan of flies (103). In brain tissues from both $\mathrm{AD}$ and PD patients, a clear increase of PERK and eIF2 $\alpha$ phosphorylation levels was also observed when compared to normal elderly controls by antibody staining $(104,105)$. Interestingly, the same mammalian PD research and others demonstrated that oral administration of a PERK inhibitor had strong neuroprotective effects on many ND models, implicating the potential use of eIF $2 \alpha$ phosphorylation as therapeutic targets, even though PERK inhibitor itself was found to have strong undesired side effects (105-107). Finally, ATF6 overexpression has been reported recently to reduce misfolded proteins and restore memory in disease animals albeit less is known about the involvement of ATF6 in neurodegenerative disorders (108).

Taken together, all these studies suggest a complicated scenario where the three parallel arms of the UPR, in comparison to its protective function, turn out to have contrasting and even opposite effects, as sustained ER stress, depending on the disease context, shifts the UPR signaling towards induction of apoptosis. Theoretically, the apoptotic effects are tuned through different downstream networks controlled by the same batch of genes, such as the ASK1 (Apoptotic-Signaling Kinase1)-JNK pathway mediated by IRE1, pro-apoptotic transcriptional factor CHOP activated by ATF6 and ATF4, as well as apoptosis-related transcription factor FoxO3 (also in section 3.5) phosphorylated by PERK and GCN2 (102, 109-111). However, when and how the UPR converts its dual effect under ND conditions of chronic and irreversible ER stress is still incompletely understood.

\subsection{Ubiquitin-proteasome system}

Coordinated activities of the UPS and autophagy, the two major protein clearance pathways, can be central to prevent the aggregation and toxicity of misfolded-prone proteins, which manifest in a number of neurological disorders. The UPS is a highly selective and tightly regulated pathway for destruction of soluble, unneeded or potentially toxic polypeptides in most cellular compartments (112). Degradation of a protein via the UPS involves two discrete and consecutive steps named conjugation and degradation: the substrate protein is tagged by covalent attachment of multiple ubiquitin molecules to synthesize a proteolytic signal during the conjugation step; thereafter, the polyubiquitinated substrate is chewed up by the $26 \mathrm{~S}$ proteasome complex with release of free and reusable ubiquitin, which is the degradation step (113).

Accumulation of ubiquitinated proteins has been reported in NDs, and an age- and disease-related decline of UPS activity has also been reported (114-116). In some cases, malfunctions of the UPS have emerged as a primary cause in the pathogenesis of neurodegenerations. In the past two decades, for instance, a direct link between an aberration in the ubiquitin system and the resulting pathology has been studied in PD.

The gene Parkin (or PARK2) codes for a ubiquitin ligase that ubiquitinates misfolded proteins targeted for proteasome-dependent degradation (117). Various deletion 
and point mutations were found in this gene leading to young-onset PD $(118,119)$. Since then, a broad array of candidate substrates for Parkin has been identified including $\alpha$-syn and its interacting protein synphilin-1, which are responsible for Lewy-body formation (120, 121). It should be noticed that by recent findings Parkin also ubiquitinates substrates on the outer membrane of mitochondria and through the UPS participates in the elimination of damaged mitochondria, which contributes to neuronal death as well when Parkin is impaired (122).

Besides, aberrations in the UPS have been implicated as a secondary consequence by disease-associated aggregations in many other cases. Cells engineered to produce or infected with unrelated protein aggregates by different research groups were shown to have the UPS stalled and destroyed $(123,124)$. Bennett et al., 2005 further found that production of protein aggregates specifically targeted to either the nucleus or cytosol led to global impairment of the UPS function in both compartments (125). Although the molecular mechanisms are undetermined, the observation of severe UPS damage in cellular compartments lacking detectable disease agent suggests UPS disruption could be an indirect phenomenon, arguing the toxic gain-of-function mediated by pathogenic protein aggregates in NDs.

\subsection{Autophagy}

Autophagy (or macro-autophagy) is a bulk clearance pathway whereby misfolded and proteasome-resistant proteins, macromolecules, and damaged or excess organelles are packaged into double-membraned vacuoles called autophagosomes, and then transported along MTs to the lysosome for degradation (126). Autophagy is normally regulated through a series of protein-coding genes defined as autophagy-related genes (ATGs) to constitutively function at a low level (127). Although autophagy in many organisms is induced primarily in adaption to nutrient deprivation, a tight relationship between autophagy and ER homeostasis is confirmed, given that many terms like "ERAD-II", "ER-quality control autophagy (ERQC)", "ER-autophagy (ERphagy)" and "ER-to-lysosome-associated degradation (ERLAD)" have been proposed to delineate variant ER pathways that intersect with the entire or selective autophagy machinery (90, 128-130).

However, the pathological connection between autophagy and neurodegeneration is not simply restricted to the ER, and is much more complex. Experimental result has supported a role for dysfunctional autophagy as a potential causative factor of NDs, since mice deficient for Atg 5 specifically in neural cells develop progressive motor and behavior deficits, accompanied by the accumulation of cytoplasmic inclusion bodies in neurons (131). The absence of Atg5 suggests the basal activity of autophagy is already essential for preventing the accumulation of abnormal proteins in the nervous system even without expressing any disease-linked mutant proteins. Not surprising that, in the presence of toxic protein aggregates, increased induction of autophagy is relatively frequent, and substantial benefits to ameliorate neuropathology are often observed with autophagy-inducing agents in a majority of transgenic mouse models of NDs $(132,133)$.

Yet there are a few exceptions that stimulation of autophagy would become counter-productive when specific stages of autophagy for clearance have been compromised by disease proteins. For example, certain tau isoform has been shown to bind the lysosomal membrane rather than enter the lysosome for degradation (35). In this context, autophagy induction seems to deliver more tau fragments to the lysosome and promote the formation of tau oligomers at the surface of these organelles. Also notably, biochemical experiment implies that $A \beta$ is generated not only in the ER and Golgi compartments but also in autophagosomes, as purified autophagic vacuoles contain both $\beta$ APP and highly activated $\gamma$-secretase, the protease cleaving $\beta$ APP to A $\beta$ (11). Moreover, autophagy is illustrated to influence $A \beta$ secretion in vivo in $\beta A P P$ transgenic mice, where autophagy deficiency reduces extracellular $A \beta$ plaque burden and leads to aberrant intra-neuronal $A \beta$ accumulation, contrary to what may be expected if autophagy only cleaned $A \beta$ (134).

Overall, autophagy responses are generally viewed as neuroprotective, and stimulating the induction of autophagy has therapeutically received great attention. Although consequences of pharmacological modulation of autophagy are still beyond our current knowledge, in specific neurodegenerative disorders where autophagic clearance mechanisms are well-understood, further promotion of autophagy might be the best interventional strategy so far.

\subsection{Target of rapamycin (TOR)}

The evolutionarily conserved protein kinase TOR has garnered significant attention for its role in neurological diseases. Biochemical purification of TOR-associated proteins has revealed that TOR is present in two complexes, TORC1 and TORC2, with distinct sets of binding partners (135). The two complexes coordinately regulate fundamental cellular behaviors, such as protein synthesis, cytoskeletal organization, cell metabolism, cell proliferation and survival. Compared to TORC1, less is known about TORC2, part of whose function is believed to impact TORC1 through positive and negative feedback mechanisms (136). As such, we will only review the linkage between TORC1 and NDs in this section.

TORC1 and its downstream pathways have been intensively shown to be altered in a variety of neurodegenerations, but the data appear to be extremely conflicting. First of all, TORC1 is a negative regulator of autophagy in response to growth factors, amino acids and cellular energy $(137,138)$. When TORC1 activity is high, Atg13 undergoes TOR-relied phosphorylation, which blocks autophagosome formation (139). In this circumstance, beneficial effects of removing pathogenic proteins were obtained when using the TOR inhibitor, rapamycin, to induce autophagy in ND models (140). In the case of tauopathies, rapamycin also suppresses TORmediated phosphorylation of S6K (ribosomal protein 
S6 kinase), and in turn inhibits S6K-catalyzed hyperphosphorylation of tau, which may foster the conversion of tau into its pathogenic form (141). On the other hand, loss of TORC1 signaling has been implied to impair synaptic plasticity and memory storage in animal models of $\mathrm{AD}$, which can be restored through upregulation of TORC1 activity (142). This is most likely because of the function of TORC1 to modulate protein synthesis required for memory consolidation, given that altered translational control has a vital role in memory and cognitive decline (143). Two well-characterized substrates of TORC1 are involved in the initiation of cap-dependent translation of mRNA: 4E-BP (eIF4E-binding protein) and S6K. Phosphorylation of 4E-BP by TORC1 leads to its dissociation from eIF4E and allows the assembly of the translation preinitiation complex (144). S6K, as mentioned earlier, actually is best known for its ability to phosphorylate 40S ribosomal protein S6 and eIF4B, which enhances the association of eIF4B with the translation preinitiation complex (145). Additionally, TORC1 is also a key mediator of ribosome biogenesis, essential for cell growth and survival (146). Taken together, it is reasonable as well that a decrease in TORC1 activity appears to be harmful and correlate with the progression of ND in clinical patients.

How to explain the discrepancy of TORC1 in degenerative disorders? To some extent, there is a chicken-and-egg scenario here: it is difficult to determine whether alteration of TORC1 signaling emerges first, then contributing to neurodegeneration, or whether activity of TORC1 is adjusted by the cell as a secondary consequence, struggling to survive in response to an existing pathological condition. The two models apparently will lead to opposite outcomes, and current information seems to support both in different physiological contexts of NDs. Alternatively, as speculated from "Norambuena A, et al. 2018" and "Polanco JC and Götz J. 2018", it is where TORC1 is functioning that matters, rather than whether it is up or down $(147,148)$. In fact, TORC1 has been detected in multiple subcellular compartments, not only in the nucleus, cytoplasm and Golgi, but also located on vacuoles/lysosomes and plasma membrane $(149,150)$. How the subcellular distribution of TORC1 affects specific cellular responses remains an open question. However, Norambuena A, et al. 2018 found that in the early stages of $\mathrm{AD}$, oligomeric $\mathrm{A} \beta$ would abrogate lysosome-localized TORC1 function by an activation of TORC1 at the plasma membrane, where tau is phosphorylated in a TORC1-dependent manner (147). In light of this, subcellular localization may be an important principle used in $\mathrm{AD}$ to enact precise spatial and temporal control of TORC1. It will be intriguing to further investigate whether it also holds true for other degenerative diseases.

\subsection{Insulin/insulin-like growth factor (IGF) signaling}

The mammalian brain has a high demand for energy. Despite representing only $2 \%$ of the total body mass, the brain consumes approximately $25 \%$ of the glucose and oxygen used by the body (151). As a matter of fact, nearly all neurodegenerations have been corroborated to exhibit a crucial metabolic dysfunction that includes altered glucose uptake/utilization and disrupted mitochondrial activity. The insulin/IGF signaling responsive to systemic hormonal cues is the main regulatory network controlling energy metabolism and longevity in multicellular animals $(152,153)$. Insulin and IGFs, closely related in terms of biological activity, are primarily secreted from different organs, yet both are also locally synthesized in the brain (154). Insulin resistance takes place when cellular responsiveness to insulin/IGFs is compromised, leading to a disturbance in glucose metabolism and energy balance. Strong evidence has underscored that type 2 diabetes and midlife obesity associated with insulin resistance are risk factors for development of dementia, PD, AD and HD (155-158).

However, contradiction appears in literatures when this comes to the level of molecular and cell biology. While some studies reported reduced expression of insulin, IGFs and their receptors in brains of AD and PD by quantitative RT-PCR, more tried to prove elevated insulin/IGFs in the serum and cerebrospinal fluid of patients with neurological diseases, including AD and PD (159-162). What is more controversial is that positive effects have been observed either by decreasing insulin/IGF signaling or by administration of agonists of insulin and IGF-1 in preclinical models $(163,164)$. Interestingly, an in vitro assay has showed that $\mathrm{A} \beta$ in $\mathrm{AD}$ is a direct competitive inhibitor on insulin binding to its receptor, indicating insulin resistance perhaps is not simply resulting from the changed amount of pathway components (165). Alternatively, the inconsistency might come from the time point chosen for investigation during the whole disease course. As indicated by a survey based on 3,139 participants for up to 10 years in Rotterdam of Netherlands, the interconnection between insulin metabolism and the clinical manifestation of ND does exist but seems not constant over time (166).

In mammals, both insulin and insulin-like growth factors (IGFs) activate the phosphatidylinositol 3-kinase (PI3K)/ AKT pathway through their respective receptors. The protein kinase AKT is recruited to the plasma membrane via phosphatidylinositol-triphosphate (PIP3), which is generated through phosphorylation of PI-4,5-P2 by PI3K. Membrane-recruited AKT then is activated and phosphorylated successively by PDK1 and by TORC2 (153). By monitoring the level of AKT phosphorylation, AKT activity has been implied to be important for neuronal survival and usually is low when cell is insulin resistant (167). Additionally, it has been shown that AKT is able to negatively interact with several pathogenic proteins via different mechanisms, complicating the regulation of AKT in NDs (168). Anyway, a chicken-and-egg analogy could also be used to summarize the interplay between neurodegenerations and AKT, similar to the situations with TORC1.

AKT has a couple of downstream effectors, including TORC1 and FoxOs, the Forkhead box class O transcription factors. Through AKT, TORC1 integrates 
information about growth factor signals and nutritional status to adjust cellular proteostasis in conditions such as NDs, which has been discussed in the previous section. In addition to TORC 1 , AKT also mediates the phosphorylation of FoxO and creates binding sites for 14-3-3 proteins, which promotes the retention of FoxO in the cytoplasm, thereby lowering its activity in the nucleus (169). The evolutionarily conserved FoxO transcription factors are well-known to modulate the expression of genes involved in cell survival, stress response, metabolism and longevity (170). Mammals have four FoxO genes, FoxO1, 3, 4 and 6, which are expressed in the nervous system at different levels with high similarity in their function and regulation $(171,172)$. The expression of FoxO overall is increasing progressively in aging human and mouse brains. In mice, nervous system specific FoxO1/3/4 loss-of-function accelerates agingrelated degeneration followed by motor dysfunction (173). By contrast, overexpression of a constitutively active FoxO3 has pro-apoptotic effects leading to neuronal loss, suggesting that fine-tuning FoxO level is of some importance to neurons. Intriguingly, inhibition of FoxO3 by expressing a dominant negative competitor is absolutely protective when a pathogenic $\alpha$-syn is coexpressed to induce a disorder condition, highlighting FoxO as a potential target for ameliorating the cytotoxicity of misfolded pathogenic proteins of NDs (174).

\section{Conclusions}

Unlike other cells in an organism, mature neurons cannot divide and usually have large expanses of dendritic and axonal cytoplasm. They consequently face particular hurdles in preventing cellular waste and misfolded proteins from accumulating over a lifetime without the aid of cell division to dilute these burdens. Young neurons achieve this task by efficient stress response and clearing systems supported by robust cellular signaling transductions. In comparison, the stereotypic neuronal connections in the elderly allow transformation and accumulation of specific proteins, such as $A \beta$, tau, $\alpha$-syn and prion, easily within the nervous system. In respect to this, aged brain quite often is the organ affected most severely under conditions of NDs with altered activities of pathways in proteostasis (Figure 1). Although it is still uncertain whether the abnormal pathway activities implicate a primary cause or secondary consequence, the current chicken-and-egg debates concerning this issue, as outlined above, definitely will provide in-depth understandings of NDs, as well as a fruitful source of knowledge for therapeutics to treat these brain symptoms in the future.

\section{Acknowledgement}

This work is supported by the National Natural Science Foundation of China (No. 31701229), Fundamental Research Funds for the Central Universities (KJQN201829) and Funding CLB20J023.

\section{Conflict of interest}

The authors declare that they have no conflict of interest.

\section{References}

1. Goedert M, Spillantini MG. A century of Alzheimer's disease. Science (New York, NY). 2006;314(5800):777-81.

2. Polymeropoulos MH, Lavedan C, Leroy E, Ide SE, Dehejia A, Dutra A, et al. Mutation in the alpha-synuclein gene identified in families with Parkinson's disease. Science (New York, NY). 1997;276(5321):2045-7

3. Gusella JF, McNeil S, Persichetti F, Srinidhi J, Novelletto A, Bird E, et al. Huntington's disease. Cold Spring Harb Symp Quant Biol. 1996;61:615-26.

4. Wallace M. Creutzfeldt-Jakob disease: assessment and management. J Gerontol Nurs. 1993;19(11):15-22.

5. Campuzano V, Montermini L, Molto MD, Pianese L, Cossee $M$, Cavalcanti $F$, et al. Friedreich's ataxia: autosomal recessive disease caused by an intronic GAA triplet repeat expansion. Science (New York, NY). 1996;271(5254):1423-7.

6. Lefebvre S, Burglen L, Reboullet S, Clermont O, Burlet P, Viollet $L$, et al. Identification and characterization of a spinal muscular atrophy-determining gene. Cell. 1995;80(1):155-65.

7. Prusiner SB. Novel proteinaceous infectious particles cause scrapie. Science (New York, NY). 1982;216(4542):136-44.

8. Vilchez D, Saez I, Dillin A. The role of protein clearance mechanisms in organismal ageing and age-related diseases. Nat Commun. 2014;5:5659.

9. Bhatt J, Comas Herrera A, Amico F, Farina N, Wong J, Orange J, et al. The world Alzheimer report 2019: attitudes to dementia2019.

10. Volgyi K, Juhasz G, Kovacs Z, Penke B. Dysfunction of endoplasmic reticulum (ER) and mitochondria (MT) in Alzheimer's disease: the role of the ER-MT cross-talk. Curr Alzheimer Res. 2015;12(7):655-72.

11. $\mathrm{Yu}$ WH, Kumar A, Peterhoff C, Shapiro Kulnane L, Uchiyama Y, Lamb BT, et al. Autophagic vacuoles are enriched in amyloid precursor protein-secretase activities: implications for beta-amyloid peptide over-production and localization in Alzheimer's disease. Int $\mathrm{J}$ Biochem Cell Biol. 2004;36(12):2531-40.

12. Bondareff W. Age-related changes in brain extracellular space affect processing of amyloid-beta peptides in Alzheimer's disease. J Alzheimers Dis. 2013;35(1):1-6.

13. Chen ZC, Zhang W, Chua LL, Chai C, Li R, Lin L, et al. Phosphorylation of amyloid precursor protein by mutant LRRK2 promotes AICD activity and neurotoxicity in Parkinson's disease. Sci Signal. 2017;10(488).

14. Stenoien DL, Cummings CJ, Adams HP, Mancini MG, Patel K, DeMartino GN, et al. Polyglutamine-expanded androgen receptors form aggregates that sequester heat shock proteins, proteasome components and SRC-1, and are suppressed by the HDJ-2 chaperone. Hum Mol Genet. 1999;8(5):731-41.

15. Schilling G, Wood JD, Duan K, Slunt HH, Gonzales V, Yamada $M$, et al. Nuclear accumulation of truncated atrophin-1 fragments in a transgenic mouse model of DRPLA. Neuron. 1999;24(1):275-86.

16. Tait $D$, Riccio $M$, Sittler $A$, Scherzinger $E$, Santi $S$, Ognibene A, et al. Ataxin-3 is transported into the nucleus and associates with the nuclear matrix. Hum Mol Genet. 1998;7(6):991-7.

17. Rousseaux MW, de Haro M, Lasagna-Reeves CA, De Maio A, Park J, Jafar-Nejad P, et al. TRIM28 regulates the nuclear accumulation and toxicity of both alpha-synuclein and tau. Elife. 2016;5

18. Pacheco C, Aguayo LG, Opazo C. An extracellular mechanism that can explain the neurotoxic effects of alphasynuclein aggregates in the brain. Front Physiol. 2012;3:297.

19. Guardia-Laguarta C, Area-Gomez E, Schon EA, Przedborski $S$. A new role for alpha-synuclein in Parkinson's disease: 
alteration of ER-mitochondrial communication. Mov Disord. 2015;30(8):1026-33.

20. Mahul-Mellier AL, Burtscher J, Maharjan N, Weerens L, Croisier M, Kuttler F, et al. The process of Lewy body formation, rather than simply alpha-synuclein fibrillization, is one of the major drivers of neurodegeneration. Proc Nat Acad Sci U S A. 2020;117(9):4971-82.

21. Ederle H, Dormann D. TDP-43 and FUS en route from the nucleus to the cytoplasm. FEBS Lett. 2017;591(11):1489-507.

22. De Rooij KE, Dorsman JC, Smoor MA, Den Dunnen JT, Van Ommen GJ. Subcellular localization of the Huntington's disease gene product in cell lines by immunofluorescence and biochemical subcellular fractionation. Hum Mol Genet. 1996;5(8):1093-9.

23. Llewelyn CA, Hewitt PE, Knight RS, Amar K, Cousens $\mathrm{S}$, Mackenzie J, et al. Possible transmission of variant Creutzfeldt-Jakob disease by blood transfusion. Lancet. 2004;363(9407):417-21.

24. Liberski PP, Gajos A, Sikorska B, Lindenbaum S. Kuru, the first human prion disease. Viruses. 2019;11(3)

25. Casalone $\mathrm{C}$, Hope J. Atypical and classic bovine spongiform encephalopathy. Handb Clin Neurol. 2018;153:121-34.

26. Dube C, Mehren KG, Barker IK, Peart BL, Balachandran A. Retrospective investigation of chronic wasting disease of cervids at the Toronto Zoo, 1973-2003. Can Vet J. 2006;47(12):1185-93.

27. Sung $\mathrm{CH}$, Davenport CM, Nathans J. Rhodopsin mutations responsible for autosomal dominant retinitis pigmentosa. Clustering of functional classes along the polypeptide chain J Biol Chem. 1993;268(35):26645-9.

28. Sirangelo I, lannuzzi C. The role of metal binding in the amyotrophic lateral sclerosis-related aggregation of copperzinc superoxide dismutase. Molecules. 2017;22(9).

29. Ochalek A, Mihalik B, Avci HX, Chandrasekaran A, Teglas A, Bock I, et al. Neurons derived from sporadic Alzheimer's disease iPSCs reveal elevated TAU hyperphosphorylation, increased amyloid levels, and GSK3B activation. Alzheimers Res Ther. 2017;9(1):90

30. Rockenstein E, Ubhi K, Mante M, Florio J, Adame A, Winter $S$, et al. Neuroprotective effects of Cerebrolysin in triple repeat Tau transgenic model of Pick's disease and frontotemporal tauopathies. BMC Neurosci. 2015;16:85.

31. Farah CA, Liazoghli D, Perreault S, Desjardins M, Guimont A, Anton A, et al. Interaction of microtubule-associated protein-2 and p63: a new link between microtubules and rough endoplasmic reticulum membranes in neurons. J Biol Chem. 2005;280(10):9439-49.

32. Farah CA, Perreault S, Liazoghli D, Desjardins M, Anton A, Lauzon M, et al. Tau interacts with Golgi membranes and mediates their association with microtubules. Cell Motil Cytoskeleton. 2006;63(11):710-24.

33. Brandt R, Leger J, Lee G. Interaction of tau with the neura plasma membrane mediated by tau's amino-terminal projection domain. J Cell Biol. 1995;131(5):1327-40.

34. Vandermeeren $M$, Mercken $M$, Vanmechelen $E$, Six J, van de Voorde A, Martin JJ, et al. Detection of tau proteins in normal and Alzheimer's disease cerebrospinal fluid with a sensitive sandwich enzyme-linked immunosorbent assay. J Neurochem. 1993;61(5):1828-34.

35. Collin L, Bohrmann B, Gopfert U, Oroszlan-Szovik K, Ozmen L, Gruninger F. Neuronal uptake of tau/pS422 antibody and reduced progression of tau pathology in a mouse model of Alzheimer's disease. Brain. 2014;137(Pt 10):2834-46.

36. Davidson Y, Kelley T, Mackenzie IR, Pickering-Brown S, Du Plessis D, Neary D, et al. Ubiquitinated pathological lesions in frontotemporal lobar degeneration contain the TAR DNA-binding protein, TDP-43. Acta Neuropathol. 2007;113(5):521-33.

37. Arai T, Hasegawa M, Akiyama H, Ikeda K, Nonaka T, Mori $\mathrm{H}$, et al. TDP-43 is a component of ubiquitin-positive taunegative inclusions in frontotemporal lobar degeneration and amyotrophic lateral sclerosis. Biochem Biophys Res
Commun. 2006;351(3):602-11.

38. Kang J, Lemaire HG, Unterbeck A, Salbaum JM, Masters $\mathrm{CL}$, Grzeschik KH, et al. The precursor of Alzheimer's disease amyloid A4 protein resembles a cell-surface receptor. Nature. 1987;325(6106):733-6.

39. Gouras GK, Tsai J, Naslund J, Vincent B, Edgar M, Checler $F$, et al. Intraneuronal Abeta42 accumulation in human brain. Am J Pathol. 2000;156(1):15-20.

40. Sisodia SS. Beta-amyloid precursor protein cleavage by a membrane-bound protease. Proc Natl Acad Sci U S A. 1992;89(13):6075-9

41. Parvathy S, Hussain I, Karran EH, Turner AJ, Hooper NM. Cleavage of Alzheimer's amyloid precursor protein by alpha-secretase occurs at the surface of neuronal cells. Biochemistry. 1999;38(30):9728-34.

42. Vassar R, Bennett BD, Babu-Khan S, Kahn S, Mendiaz EA, Denis P, et al. Beta-secretase cleavage of Alzheimer's amyloid precursor protein by the transmembrane aspartic protease BACE. Science. 1999;286(5440):735-41.

43. Qi-Takahara $\mathrm{Y}$, Morishima-Kawashima M, Tanimura $\mathrm{Y}$, Dolios G, Hirotani N, Horikoshi Y, et al. Longer forms of amyloid beta protein: implications for the mechanism of intramembrane cleavage by gamma-secretase. J Neurosci. 2005;25(2):436-45.

44. Carter DB, Dunn E, Pauley AM, McKinley DD, Fleck TJ, Ellerbrook BR, et al. Changes in gamma-secretase activity and specificity caused by the introduction of consensus aspartyl protease active motif in Presenilin 1. Mol Neurodegener. 2008;3:6.

45. Xu H, Sweeney D, Wang R, Thinakaran G, Lo AC, Sisodia SS, et al. Generation of Alzheimer beta-amyloid protein in the trans-Golgi network in the apparent absence of vesicle formation. Proc Natl Acad Sci U S A. 1997;94(8):3748-52.

46. Gravina SA, Ho L, Eckman CB, Long KE, Otvos $\mathrm{L}$, Jr., Younkin LH, et al. Amyloid beta protein (A beta) in Alzheimer's disease brain. Biochemical and immunocytochemical analysis with antibodies specific for forms ending at A beta 40 or A beta 42(43). J Biol Chem. 1995;270(13):7013-6.

47. Iwatsubo $\mathrm{T}$, Odaka A, Suzuki N, Mizusawa H, Nukina $\mathrm{N}$ Ihara Y. Visualization of A beta 42(43) and A beta 40 in senile plaques with end-specific A beta monoclonals: evidence that an initially deposited species is A beta 42(43). Neuron. 1994;13(1):45-53.

48. Pimenova AA, Raj T, Goate AM. Untangling genetic risk for Alzheimer's disease. Biol Psychiatry. 2018;83(4):300-10.

49. Zhong Z, Quon D, Higgins LS, Higaki J, Cordell B. Increased amyloid production from aberrant beta-amyloid precursor proteins. J Biol Chem. 1994;269(16):12179-84.

50. Zhou R, Yang G, Guo X, Zhou Q, Lei J, Shi Y. Recognition of the amyloid precursor protein by human gamma-secretase. Science. 2019;363(6428).

51. Gu Y, Misonou H, Sato T, Dohmae N, Takio K, Ihara $Y$. Distinct intramembrane cleavage of the beta-amyloid precursor protein family resembling gamma-secretase-like cleavage of Notch. J Biol Chem. 2001;276(38):35235-8.

52. Nilsberth $C$, Westlind-Danielsson A, Eckman CB, Condron MM, Axelman K, Forsell C, et al. The 'Arctic' APP mutation (E693G) causes Alzheimer's disease by enhanced Abeta protofibril formation. Nat Neurosci. 2001;4(9):887-93.

53. Philipson O, Lord A, Lalowski M, Soliymani R, Baumann $M$, Thyberg J, et al. The Arctic amyloid-beta precursor protein (AbetaPP) mutation results in distinct plaques and accumulation of $\mathrm{N}$ - and $\mathrm{C}$-truncated Abeta. Neurobiol Aging. 2012;33(5):1010 e1-13.

54. Lannfelt L, Bogdanovic N, Appelgren H, Axelman K, Lilius $L$, Hansson G, et al. Amyloid precursor protein mutation causes Alzheimer's disease in a Swedish family. Neurosci Lett. 1994;168(1-2):254-6.

55. Rogaev EI, Sherrington R, Rogaeva EA, Levesque G, Ikeda $M$, Liang $Y$, et al. Familial Alzheimer's disease in kindreds 
with missense mutations in a gene on chromosome 1 related to the Alzheimer's disease type 3 gene. Nature. 1995;376(6543):775-8.

56. Kimberly WT, LaVoie MJ, Ostaszewski BL, Ye W, Wolfe MS, Selkoe DJ. Gamma-secretase is a membrane protein complex comprised of presenilin, nicastrin, Aph-1, and Pen2. Proc Natl Acad Sci U S A. 2003;100(11):6382-7.

57. Sun L, Zhou R, Yang G, Shi Y. Analysis of 138 pathogenic mutations in presenilin-1 on the in vitro production of Abeta42 and Abeta40 peptides by gamma-secretase. Proc Natl Acad Sci U S A. 2017;114(4):E476-E85.

58. Saunders AM, Strittmatter WJ, Schmechel D, GeorgeHyslop PH, Pericak-Vance MA, Joo SH, et al. Association of apolipoprotein $\mathrm{E}$ allele epsilon 4 with late-onset familial and sporadic Alzheimer's disease. Neurology. 1993;43(8):1467-72

59. Namba $\mathrm{Y}$, Tomonaga M, Kawasaki H, Otomo E, Ikeda K. Apolipoprotein $\mathrm{E}$ immunoreactivity in cerebral amyloid deposits and neurofibrillary tangles in Alzheimer's disease and kuru plaque amyloid in Creutzfeldt-Jakob disease. Brain Res. 1991;541(1):163-6.

60. Bales KR, Verina T, Dodel RC, Du Y, Altstiel L, Bender M, et al. Lack of apolipoprotein $E$ dramatically reduces amyloid beta-peptide deposition. Nat Genet. 1997;17(3):263-4.

61. Spillantini MG, Goedert M, Crowther RA, Murrell JR, Farlow MR, Ghetti B. Familial multiple system tauopathy with presenile dementia: a disease with abundant neuronal and glial tau filaments. Proc Natl Acad Sci U S A. 1997;94(8):4113-8.

62. Cleveland DW, Hwo SY, Kirschner MW. Physical and chemical properties of purified tau factor and the role of tau in microtubule assembly. J Mol Biol. 1977;116(2):227-47.

63. Alonso AC, Zaidi T, Grundke-Iqbal I, Iqbal K. Role of abnormally phosphorylated tau in the breakdown of microtubules in Alzheimer disease. Proc Natl Acad Sci U S A 1994;91(12):5562-6.

64. Goedert M, Spillantini MG, Cairns NJ, Crowther RA. Tau proteins of Alzheimer paired helical filaments: abnorma phosphorylation of all six brain isoforms. Neuron. 1992;8(1):159-68.

65. Berriman J, Serpell LC, Oberg KA, Fink AL, Goedert M Crowther RA. Tau filaments from human brain and from in vitro assembly of recombinant protein show cross-beta structure. Proc Natl Acad Sci U S A. 2003;100(15):9034-8.

66. Crowther RA, Goedert M. Abnormal tau-containing filaments in neurodegenerative diseases. J Struct Biol. 2000;130(2-3):271-9.

67. Frost $B$, Jacks RL, Diamond MI. Propagation of tau misfolding from the outside to the inside of a cell. $\mathrm{J}$ Biol Chem. 2009;284(19):12845-52.

68. Mudher A, Shepherd D, Newman TA, Mildren P, Jukes JP, Squire A, et al. GSK-3beta inhibition reverses axonal transport defects and behavioural phenotypes in Drosophila. Mol Psychiatry. 2004;9(5):522-30.

69. Yao J, Irwin RW, Zhao L, Nilsen J, Hamilton RT, Brinton $\mathrm{RD}$. Mitochondrial bioenergetic deficit precedes Alzheimer's pathology in female mouse model of Alzheimer's disease. Proc Natl Acad Sci U S A. 2009;106(34):14670-5

70. Stamer K, Vogel R, Thies E, Mandelkow E, Mandelkow EM Tau blocks traffic of organelles, neurofilaments, and APP vesicles in neurons and enhances oxidative stress. J Cell Biol. 2002;156(6):1051-63.

71. Burre J, Sharma M, Tsetsenis T, Buchman V, Etherton MR Sudhof TC. Alpha-synuclein promotes SNARE-complex assembly in vivo and in vitro. Science. 2010;329(5999):1663-7.

72. Vinueza-Gavilanes R, Inigo-Marco I, Larrea L, Lasa M, Carte $B$, Santamaria E, et al. N-terminal acetylation mutants affect alpha-synuclein stability, protein levels and neuronal toxicity. Neurobiol Dis. 2020;137:104781.

73. Maltsev AS, Ying J, Bax A. Impact of N-terminal acetylation of alpha-synuclein on its random coil and lipid binding properties. Biochemistry. 2012;51(25):5004-13.
74. Shahmoradian SH, Lewis AJ, Genoud C, Hench J, Moors TE, Navarro PP, et al. Lewy pathology in Parkinson's disease consists of crowded organelles and lipid membranes. Nat Neurosci. 2019;22(7):1099-109.

75. Braak H, Del Tredici K, Rub U, de Vos RA, Jansen Steur EN, Braak E. Staging of brain pathology related to sporadic Parkinson's disease. Neurobiol Aging. 2003;24(2):197-211.

76. Jensen $\mathrm{PH}$, Hojrup $\mathrm{P}$, Hager $\mathrm{H}$, Nielsen MS, Jacobsen $\mathrm{L}$, Olesen OF, et al. Binding of Abeta to alpha- and betasynucleins: identification of segments in alpha-synuclein/ NAC precursor that bind Abeta and NAC. Biochem J. 1997;323 ( Pt 2):539-46.

77. Jensen $\mathrm{PH}$, Sorensen ES, Petersen TE, Gliemann J, Rasmussen LK. Residues in the synuclein consensus motif of the alpha-synuclein fragment, NAC, participate in transglutaminase-catalysed cross-linking to Alzheimer-disease amyloid beta A4 peptide. Biochem J. 1995;310 ( Pt 1):91-4.

78. Prusiner SB. Prions. Proc Natl Acad Sci U S A. 1998;95(23):13363-83.

79. Asante EA, Linehan JM, Smidak M, Tomlinson A, Grimshaw $A$, Jeelani $A$, et al. Inherited prion disease $A 117 \mathrm{~V}$ is not simply a proteinopathy but produces prions transmissible to transgenic mice expressing homologous prion protein. PLoS Pathog. 2013;9(9):e1003643

80. Jackson WS, Borkowski AW, Watson NE, King OD, Faas $H$, Jasanoff $A$, et al. Profoundly different prion diseases in knock-in mice carrying single PrP codon substitutions associated with human diseases. Proc Natl Acad Sci U S A. 2013;110(36):14759-64

81. Seelig DM, Goodman PA, Skinner PJ. Potential approaches for heterologous prion protein treatment of prion diseases. Prion. 2016;10(1):18-24.

82. Holec SAM, Yuan Q, Bartz JC. Alteration of Prion Strain Emergence by Nonhost Factors. mSphere. 2019;4(5).

83. Maddison BC, Baker CA, Terry LA, Bellworthy SJ, Thorne L, Rees HC, et al. Environmental sources of scrapie prions. J Virol. 2010;84(21):11560-2.

84. Caughey B, Baron GS, Chesebro B, Jeffrey M. Getting a grip on prions: oligomers, amyloids, and pathological membrane interactions. Annu Rev Biochem. 2009;78:177-204.

85. Concha-Marambio L, Pritzkow S, Moda F, Tagliavini F, Ironside JW, Schulz PE, et al. Detection of prions in blood from patients with variant Creutzfeldt-Jakob disease. Sci TransI Med. 2016;8(370):370ra183.

86. Kane MD, Lipinski WJ, Callahan MJ, Bian F, Durham RA, Schwarz RD, et al. Evidence for seeding of beta -amyloid by intracerebral infusion of Alzheimer brain extracts in beta -amyloid precursor protein-transgenic mice. J Neurosci. 2000;20(10):3606-11.

87. Clavaguera F, Hench J, Lavenir I, Schweighauser G, Frank S Goedert M, et al. Peripheral administration of tau aggregates triggers intracerebral tauopathy in transgenic mice. Acta Neuropathol. 2014;127(2):299-301.

88. Luk KC, Kehm V, Carroll J, Zhang B, O'Brien P, Trojanowski $\mathrm{JQ}$, et al. Pathological alpha-synuclein transmission initiates Parkinson-like neurodegeneration in nontransgenic mice. Science. 2012;338(6109):949-53.

89. Zafar S, Noor A, Zerr I. Therapies for prion diseases. Handb Clin Neurol. 2019;165:47-58.

90. Fujita E, Kouroku Y, Isoai A, Kumagai H, Misutani A, Matsuda $\mathrm{C}$, et al. Two endoplasmic reticulum-associated degradation (ERAD) systems for the novel variant of the mutant dysferlin: ubiquitin/proteasome $\operatorname{ERAD}(\mathrm{I})$ and autophagy/lysosome ERAD(II). Hum Mol Genet. 2007;16(6):618-29.

91. Hetz C, Saxena S. ER stress and the unfolded protein response in neurodegeneration. Nat Rev Neurol. 2017;13(8):477-91.

92. Szegezdi E, Logue SE, Gorman AM, Samali A. Mediators of endoplasmic reticulum stress-induced apoptosis. EMBO Rep. 2006;7(9):880-5.

93. Paz Gavilan M, Vela J, Castano A, Ramos B, del Rio JC, 
Vitorica J, et al. Cellular environment facilitates protein accumulation in aged rat hippocampus. Neurobiol Aging. 2006;27(7):973-82.

94. Taylor RC, Dillin A. XBP-1 is a cell-nonautonomous regulator of stress resistance and longevity. Cell. 2013;153(7):1435-47.

95. Calfon M, Zeng H, Urano F, Till JH, Hubbard SR, Harding $\mathrm{HP}$, et al. IRE1 couples endoplasmic reticulum load to secretory capacity by processing the XBP-1 mRNA. Nature. 2002;415(6867):92-6.

96. Sriburi R, Bommiasamy $H$, Buldak GL, Robbins GR, Frank $\mathrm{M}$, Jackowski $\mathrm{S}$, et al. Coordinate regulation of phospholipid biosynthesis and secretory pathway gene expression in XBP-1(S)-induced endoplasmic reticulum biogenesis. J Biol Chem. 2007;282(10):7024-34.

97. Haze K, Yoshida H, Yanagi H, Yura T, Mori K. Mammalian transcription factor ATF6 is synthesized as a transmembrane protein and activated by proteolysis in response to endoplasmic reticulum stress. Mol Biol Cell. 1999;10(11):3787-99.

98. Baird TD, Wek RC. Eukaryotic initiation factor 2 phosphorylation and translational control in metabolism. Adv Nutr. 2012;3(3):307-21.

99. Kang K, Ryoo HD, Park JE, Yoon JH, Kang MJ. A Drosophila reporter for the translational activation of ATF4 marks stressed cells during development. PLoS One. 2015;10(5):e0126795.

100. Zhang W, Neo SP, Gunaratne J, Poulsen A, Boping L, Ong $\mathrm{EH}$, et al. Feedback regulation on PTEN/AKT pathway by the ER stress kinase PERK mediated by interaction with the Vault complex. Cell Signal. 2015;27(3):436-42.

101. Hamanaka RB, Bennett BS, Cullinan SB, Diehl JA. PERK and GCN2 contribute to elF2alpha phosphorylation and cel cycle arrest after activation of the unfolded protein response pathway. Mol Biol Cell. 2005;16(12):5493-501.

102. You S, Li H, Hu Z, Zhang W. elF2alpha kinases PERK and GCN2 act on FOXO to potentiate FOXO activity. Genes Cells. 2018;23(9):786-93

103. Yan C, Liu J, Gao J, Sun Y, Zhang L, Song H, et al. IRE promotes neurodegeneration through autophagy-dependent neuron death in the Drosophila model of Parkinson's disease. Cell Death Dis. 2019;10(11):800.

104. Stutzbach LD, Xie SX, Naj AC, Albin R, Gilman S, Group PSPGS, et al. The unfolded protein response is activated in disease-affected brain regions in progressive supranuclear palsy and Alzheimer's disease. Acta Neuropathol Commun. 2013:1:31.

105. Mercado G, Castillo V, Soto P, Lopez N, Axten JM, Sardi $\mathrm{SP}$, et al. Targeting PERK signaling with the small molecule GSK2606414 prevents neurodegeneration in a model of Parkinson's disease. Neurobiol Dis. 2018;112:136-48.

106. Elvira R, Cha SJ, Noh GM, Kim K, Han J. PERK-mediated elF2alpha phosphorylation contributes to the protection of dopaminergic neurons from chronic heat stress in Drosophila. Int J Mol Sci. 2020;21(3).

107. Radford H, Moreno JA, Verity N, Halliday M, Mallucci GR PERK inhibition prevents tau-mediated neurodegeneration in a mouse model of frontotemporal dementia. Acta Neuropathol. 2015;130(5):633-42.

108. Egawa N, Yamamoto K, Inoue H, Hikawa R, Nishi K, Mori K, et al. The endoplasmic reticulum stress sensor, ATF6alpha, protects against neurotoxin-induced dopaminergic neuronal death. J Biol Chem. 2011;286(10):7947-57.

109. Zhang W, Hietakangas V, Wee S, Lim SC, Gunaratne J, Cohen SM. ER stress potentiates insulin resistance through PERK-mediated FOXO phosphorylation. Genes Dev. 2013;27(4):441-9.

110. Cai DT, Jin H, Xiong QX, Liu WG, Gao ZG, Gu GX, et al. ER stress and ASK1-JNK activation contribute to oridonininduced apoptosis and growth inhibition in cultured human hepatoblastoma HuH-6 cells. Mol Cell Biochem. 2013;379(1-2):161-9.
111. Marciniak SJ, Yun CY, Oyadomari S, Novoa I, Zhang $\mathrm{Y}$, Jungreis $\mathrm{R}$, et al. CHOP induces death by promoting protein synthesis and oxidation in the stressed endoplasmic reticulum. Genes Dev. 2004;18(24):3066-77

112. Ciechanover A, Orian A, Schwartz AL. Ubiquitin-mediated proteolysis: biological regulation via destruction. Bioessays. 2000;22(5):442-51.

113. Ciechanover A, Brundin P. The ubiquitin proteasome system in neurodegenerative diseases: sometimes the chicken, sometimes the egg. Neuron. 2003;40(2):427-46.

114. Fornai F, Schluter OM, Lenzi P, Gesi M, Ruffoli R, Ferrucci $M$, et al. Parkinson-like syndrome induced by continuous MPTP infusion: convergent roles of the ubiquitin-proteasome system and alpha-synuclein. Proc Natl Acad Sci U S A. 2005;102(9):3413-8.

115. Tonoki A, Kuranaga E, Tomioka T, Hamazaki J, Murata S, Tanaka K, et al. Genetic evidence linking age-dependent attenuation of the $26 \mathrm{~S}$ proteasome with the aging process. Mol Cell Biol. 2009;29(4):1095-106.

116. Benvegnu S, Mateo MI, Palomer E, Jurado-Arjona J, Dotti CG. Aging triggers cytoplasmic depletion and nuclear translocation of the E3 ligase mahogunin: a function for ubiquitin in neuronal survival. Mol Cell. 2017;66(3):358-72 e7.

117. Imai Y, Soda M, Takahashi R. Parkin suppresses unfolded protein stress-induced cell death through its E3 ubiquitinprotein ligase activity. J Biol Chem. 2000;275(46):35661-4.

118. Takahashi H, Ohama E, Suzuki S, Horikawa $Y$, Ishikawa A Morita $\mathrm{T}$, et al. Familial juvenile parkinsonism: clinical and pathologic study in a family. Neurology. 1994;44(3 Pt 1):437-41.

119. Dwork AJ, Balmaceda C, Fazzini EA, MacCollin M, Cote L, Fahn S. Dominantly inherited, early-onset parkinsonism: neuropathology of a new form. Neurology. 1993;43(1):69-74.

120. Spillantini MG, Schmidt ML, Lee VM, Trojanowski JQ, Jakes $\mathrm{R}$, Goedert M. Alpha-synuclein in Lewy bodies. Nature. 1997;388(6645):839-40.

121. Engelender S, Kaminsky Z, Guo X, Sharp AH, Amaravi RK, Kleiderlein JJ, et al. Synphilin-1 associates with alphasynuclein and promotes the formation of cytosolic inclusions. Nat Genet. 1999;22(1):110-4.

122. Ziviani E, Tao RN, Whitworth AJ. Drosophila parkin requires PINK1 for mitochondrial translocation and ubiquitinates mitofusin. Proc Natl Acad Sci U S A. 2010;107(11):5018-23.

123. Bence NF, Sampat RM, Kopito RR. Impairment of the ubiquitin-proteasome system by protein aggregation. Science. 2001;292(5521):1552-5

124. Verhoef LG, Lindsten K, Masucci MG, Dantuma NP. Aggregate formation inhibits proteasomal degradation of polyglutamine proteins. Hum Mol Genet. 2002;11(22):2689-700.

125. Bennett EJ, Bence NF, Jayakumar R, Kopito RR. Global impairment of the ubiquitin-proteasome system by nuclear or cytoplasmic protein aggregates precedes inclusion body formation. Mol Cell. 2005;17(3):351-65.

126. Galluzzi L, Pietrocola F, Levine B, Kroemer G. Metabolic control of autophagy. Cell. 2014;159(6):1263-76

127. Levine B, Kroemer G. Biological Functions of autophagy genes: a disease perspective. Cell. 2019;176(1-2):11-42.

128. Bernales S, Schuck S, Walter P. ER-phagy: selective autophagy of the endoplasmic reticulum. Autophagy. 2007;3(3):285-7

129. Lipatova Z, Segev N. A Role for Macro-ER-Phagy in ER Quality Control. PLoS Genet. 2015;11(7):e1005390.

130. Fregno I, Fasana E, Bergmann TJ, Raimondi A, Loi M, Solda $T$, et al. ER-to-lysosome-associated degradation of proteasome-resistant ATZ polymers occurs via receptormediated vesicular transport. EMBO J. 2018;37(17).

131. Xi Y, Dhaliwal JS, Ceizar M, Vaculik M, Kumar KL, Lagace DC. Knockout of Atg5 delays the maturation and reduces the survival of adult-generated neurons in the hippocampus. Cell Death Dis. 2016;7:e2127.

132. Shoji-Kawata S, Sumpter R, Leveno M, Campbell GR, Zou $Z$, Kinch $L$, et al. Identification of a candidate therapeutic 
autophagy-inducing peptide. Nature. 2013;494(7436):201-6.

133. Castillo K, Nassif M, Valenzuela V, Rojas F, Matus S, Mercado $G$, et al. Trehalose delays the progression of amyotrophic lateral sclerosis by enhancing autophagy in motoneurons. Autophagy. 2013;9(9):1308-20.

134. Nilsson $P$, Loganathan K, Sekiguchi M, Matsuba $Y, \mathrm{Hu}$ $\mathrm{K}$, Tsubuki $\mathrm{S}$, et al. Abeta secretion and plaque formation depend on autophagy. Cell Rep. 2013;5(1):61-9.

135. Loewith R, Jacinto E, Wullschleger S, Lorberg A, Crespo JL, Bonenfant $D$, et al. Two TOR complexes, only one of which is rapamycin sensitive, have distinct roles in cell growth control. Mol Cell. 2002;10(3):457-68.

136. Hietakangas V, Cohen SM. Re-evaluating AKT regulation: role of TOR complex 2 in tissue growth. Genes Dev. 2007;21(6):632-7

137. Hahn-Windgassen A, Nogueira V, Chen CC, Skeen JE, Sonenberg $\mathrm{N}$, Hay $\mathrm{N}$. Akt activates the mammalian target of rapamycin by regulating cellular ATP level and AMPK activity. J Biol Chem. 2005;280(37):32081-9.

138. Beugnet A, Tee AR, Taylor PM, Proud CG. Regulation of targets of mTOR (mammalian target of rapamycin) signalling by intracellular amino acid availability. Biochem $\mathrm{J}$ 2003;372(Pt 2):555-66.

139. Hosokawa N, Hara T, Kaizuka T, Kishi C, Takamura A, Miura $Y$, et al. Nutrient-dependent mTORC1 association with the ULK1-Atg13-FIP200 complex required for autophagy. Mo Biol Cell. 2009;20(7):1981-91.

140. Spilman P, Podlutskaya N, Hart MJ, Debnath J, Gorostiza $\mathrm{O}$, Bredesen $\mathrm{D}$, et al. Inhibition of mTOR by rapamycin abolishes cognitive deficits and reduces amyloid-beta levels in a mouse model of Alzheimer's disease. PLoS One. 2010;5(4):e9979.

141. Ozcelik S, Fraser G, Castets P, Schaeffer V, Skachokova $Z$, Breu K, et al. Rapamycin attenuates the progression of tau pathology in P301S tau transgenic mice. PLoS One. 2013;8(5):e62459.

142. Ma T, Hoeffer CA, Capetillo-Zarate E, Yu F, Wong H, Lin $\mathrm{MT}$, et al. Dysregulation of the mTOR pathway mediates impairment of synaptic plasticity in a mouse model of Alzheimer's disease. PLoS One. 2010;5(9).

143. Roesler R. Molecular mechanisms controlling protein synthesis in memory reconsolidation. Neurobiol Learn Mem. 2017;142(Pt A):30-40.

144. Beretta L, Gingras AC, Svitkin YV, Hall MN, Sonenberg N. Rapamycin blocks the phosphorylation of 4E-BP1 and inhibits cap-dependent initiation of translation. EMBO J. 1996;15(3):658-64.

145. Holz MK, Ballif BA, Gygi SP, Blenis J. mTOR and S6K1 mediate assembly of the translation preinitiation complex through dynamic protein interchange and ordered phosphorylation events. Cell. 2005;123(4):569-80.

146. Liu Y, Mattila J, Ventela S, Yadav L, Zhang W, Lamichane $\mathrm{N}$, et al. PWP1 Mediates Nutrient-Dependent Growth Control through Nucleolar Regulation of Ribosomal Gene Expression. Dev Cell. 2017;43(2):240-52 e5.

147. Norambuena A, Wallrabe H, Cao R, Wang DB, Silva A Svindrych $Z$, et al. A novel lysosome-to-mitochondria signaling pathway disrupted by amyloid-beta oligomers. EMBO J. 2018;37(22).

148. Polanco JC, Gotz J. Are you TORCing tau me? Amyloidbeta blocks the conversation between lysosomes and mitochondria. EMBO J. 2018;37(22).

149. Arias E, Koga H, Diaz A, Mocholi E, Patel B, Cuervo AM. Lysosomal mTORC2/PHLPP1/Akt regulate chaperonemediated autophagy. Mol Cell. 2015;59(2):270-84.

150. Reinke A, Anderson S, McCaffery JM, Yates J, 3rd, Aronova $\mathrm{S}$, Chu S, et al. TOR complex 1 includes a novel component, Tco89p (YPL180w), and cooperates with Ssd1p to maintain cellular integrity in Saccharomyces cerevisiae. J Biol Chem. 2004;279(15):14752-62.

151. Attwell D, Laughlin SB. An energy budget for signaling in the grey matter of the brain. $\mathrm{J}$ Cereb Blood Flow Metab. 2001;21(10):1133-45.

152. White MF. IRS2 integrates insulin/IGF1 signalling with metabolism, neurodegeneration and longevity. Diabetes Obes Metab. 2014;16 Suppl 1:4-15.

153. Zhang W, Thompson BJ, Hietakangas V, Cohen SM MAPK/ERK signaling regulates insulin sensitivity to control glucose metabolism in Drosophila. PLoS Genet. 2011;7(12):e1002429

154. Adamo M, Raizada MK, LeRoith D. Insulin and insulinlike growth factor receptors in the nervous system. Mol Neurobiol. 1989;3(1-2):71-100.

155. Callisaya M, Nosaka K. Effects of exercise on type 2 diabetes mellitus-related cognitive impairment and dementia. J Alzheimers Dis. 2017;59(2):503-13.

156. Cereda E, Barichella M, Pedrolli C, Klersy C, Cassani E, Caccialanza R, et al. Diabetes and risk of Parkinson's disease: a systematic review and meta-analysis. Diabetes Care. 2011;34(12):2614-23.

157. Sridhar GR, Lakshmi G, Nagamani G. Emerging links between type 2 diabetes and Alzheimer's disease. World $\mathrm{J}$ Diabetes. 2015;6(5):744-51.

158. Montojo MT, Aganzo M, Gonzalez N. Huntington's disease and diabetes: chronological sequence of its association. J Huntingtons Dis. 2017;6(3):179-88.

159. Steen E, Terry BM, Rivera EJ, Cannon JL, Neely TR, Tavares $\mathrm{R}$, et al. Impaired insulin and insulin-like growth factor expression and signaling mechanisms in Alzheimer's disease--is this type 3 diabetes? J Alzheimers Dis. 2005;7(1):63-80.

160. Tong M, Dong M, de la Monte SM. Brain insulin-like growth factor and neurotrophin resistance in Parkinson's disease and dementia with Lewy bodies: potential role of manganese neurotoxicity. J Alzheimers Dis. 2009;16(3):585-99.

161. Vardy ER, Rice PJ, Bowie PC, Holmes JD, Grant PJ, Hooper NM. Increased circulating insulin-like growth factor-1 in late-onset Alzheimer's disease. J Alzheimers Dis. 2007;12(4):285-90.

162. Godau J, Herfurth M, Kattner B, Gasser T, Berg D. Increased serum insulin-like growth factor 1 in early idiopathic Parkinson's disease. J Neurol Neurosurg Psychiatry. 2010;81(5):536-8

163. Carro E, Trejo JL, Gomez-Isla T, LeRoith D, Torres-Aleman I. Serum insulin-like growth factor I regulates brain amyloidbeta levels. Nat Med. 2002;8(12):1390-7.

164. Krishnamurthi R, Stott S, Maingay M, Faull RL, McCarthy D, Gluckman P, et al. N-terminal tripeptide of IGF-1 improves functional deficits after 6-OHDA lesion in rats. Neuroreport. 2004;15(10):1601-4

165. Xie L, Helmerhorst E, Taddei K, Plewright B, Van Bronswijk W, Martins R. Alzheimer's beta-amyloid peptides compete for insulin binding to the insulin receptor. J Neurosci. 2002;22(10):RC221.

166. Schrijvers EM, Witteman JC, Sijbrands EJ, Hofman A, Koudstaal PJ, Breteler MM. Insulin metabolism and the risk of Alzheimer disease: the Rotterdam Study. Neurology. 2010;75(22):1982-7

167. Lee HK, Kwon B, Lemere CA, de la Monte S, Itamura $\mathrm{K}$, Ha AY, et al. mTORC2 (Rictor) in Alzheimer's disease and reversal of amyloid-beta expression-induced insulin resistance and toxicity in rat primary cortical neurons. J Alzheimers Dis. 2017;56(3):1015-36.

168. Palmieri M, Pal R, Nelvagal HR, Lotfi P, Stinnett GR, Seymour ML, et al. mTORC1-independent TFEB activation via Akt inhibition promotes cellular clearance in neurodegenerative storage diseases. Nat Commun. 2017:8:14338

169. Brunet A, Bonni A, Zigmond MJ, Lin MZ, Juo P, Hu LS, et al. Akt promotes cell survival by phosphorylating and inhibiting a Forkhead transcription factor. Cell. 1999;96(6):857-68.

170. Huang $\mathrm{H}$, Tindall DJ. Dynamic FoxO transcription factors. $J$ 
Cell Sci. 2007;120(Pt 15):2479-87.

171. Paik JH, Ding Z, Narurkar R, Ramkissoon S, Muller F, Kamoun WS, et al. FoxOs cooperatively regulate diverse pathways governing neural stem cell homeostasis. Cel Stem Cell. 2009;5(5):540-53.

172. Hoekman MF, Jacobs FM, Smidt MP, Burbach JP. Spatial and temporal expression of FoxO transcription factors in the developing and adult murine brain. Gene Expr Patterns.
2006;6(2):134-40.

173. Hwang I, Oh H, Santo E, Kim DY, Chen JW, Bronson $\mathrm{RT}$, et al. FOXO protects against age-progressive axonal degeneration. Aging Cell. 2018;17(1).

174. Pino E, Amamoto R, Zheng L, Cacquevel M, Sarria JC, Knott $\mathrm{GW}$, et al. FOXO3 determines the accumulation of alphasynuclein and controls the fate of dopaminergic neurons in the substantia nigra. Hum Mol Genet. 2014;23(6):1435-52. 